\title{
Overview: The international group for indigenous health measurement and COVID-19
}

\author{
Michele Connolly ${ }^{\mathrm{a}, *}$, Kalinda Griffiths ${ }^{\mathrm{b}}$, John Waldon ${ }^{\mathrm{c}}$, Malcolm King ${ }^{\mathrm{d}}$, Alexandra King ${ }^{\mathrm{e}}$ and \\ Francis C. Notzon ${ }^{\mathrm{f}}$ \\ anternational Group for Indigenous Health Measurement, Special Populations Editor, Statistical Journal of the \\ IAOS, Columbia, MD, USA \\ ${ }^{\mathrm{b}}$ Centre for Big Data Research in Health, University of New South Wales; Wellbeing and Preventable Chronic \\ Diseases Division, Menzies School of Health Research; Centre for Health Equity, University of Melbourne, Darwin, \\ Northern Territory, Australia \\ ${ }^{\mathrm{c}}$ National Centre for Cultural Competence, The University of Sydney, Palmerston, New Zealand \\ ${ }^{\mathrm{d}}$ Community Health and Epidemiology, University of Saskatchewan, Saskatoon, Saskatchewan, Canada \\ ${ }^{\mathrm{e}}$ Cameco Chair in Indigenous Health and Wellness, University of Saskatchewan, Saskatoon, Saskatchewan, Canada \\ ${ }_{\mathrm{f}}^{\mathrm{f}}$ International Group for Indigenous Health Measurement, Kensington, MD, USA
}

\begin{abstract}
The International Group for Indigenous Health Measurement (IGIHM) is a 4-country group established to promote improvements in the collection, analysis, interpretation and dissemination of Indigenous health data, including the impact of COVID-19. This overview provides data on cases and deaths for the total population as well as the Indigenous populations of each country. Brief summaries of the impact are provided for Canada and New Zealand. The Overview is followed by separate articles in this edition with more detailed discussion of the COVID-19 experience in Australia and the US.
\end{abstract}

Keywords: Indigenous, health data, SARS-CoV-2, health inequities, cultural traditions

\section{Introduction}

The March 2019 issue (Volume 35) of the SJIAOS was dedicated to the International Group for Indigenous Health Measurement (IGIHM), specifically identification issues in its four member nations of Australia, Canada, New Zealand and the United States, along with Brazil [1-5]. Other papers were included on the history of IGIHM [6], an overview of identification in general [7] and other matters. This edition contains papers on the impact of and efforts to tackle COVID-19 in two

\footnotetext{
*Corresponding author: Michele Connolly, International Group for Indigenous Health Measurement, Special Populations Editor, Statistical Journal of the IAOS, Columbia, MD, USA. E-mail: michelebabb @verizon.net.
}

of the four IGIHM countries (Australia and the United States).

Although each country contains Indigenous populations, there are more similarities than differences. One year after the SJIAOS publication, IGIHM confronted a new reality: the COVID-19 pandemic. IGIHM members held weekly, rather than monthly meetings over several months about COVID in their respective countries. Since members include Indigenous and non-Indigenous researchers, physicians, academics and community members, these meetings were a source of both solidarity and information.

While Indigenous populations in all four countries have health disparities, these communities are working to keep cultural traditions, and thus, communities strong. Statistics are part of this effort, because statis- 
tics and data enable people to tell their stories and address concerns. When statistics are limited, either due to invisibility (not being able to break out Indigenous groups) or lack of data sovereignty, statistical analyses prevent Indigenous people from being included in policy, program and medical efforts. This general lack, along with health disparities, could lead to Indigenous peoples being overlooked in tracking, treating and overcoming COVID-19.

\section{Background}

Indigenous peoples have always collected, represented, held, stored and shared data and information in a variety of forms. Issues with the collection of data and disaggregation of Indigenous peoples' data within nations were identified in the first and second sessions of the United Nations Permanent Forum on Indigenous Issues $[8,9]$. These issues impact the official statistics capabilities within nations, including the ability to provide accurate population level surveillance during global pandemics. Further discussion on the topics occurred at the United Nations Expert Workshop on Data Collection and Disaggregation for Indigenous Peoples in January 2004.

The workshop brought together 36 experts from the United Nations and around the world to examine challenges and make recommendations concerning data collection and disaggregation of Indigenous peoples in official reporting [10]. This moment represents early, expert international discussions by Indigenous peoples on the principles and frameworks of rights-based participation in the collection and use of Indigenous data.

\section{International Group for Indigenous Health Measurement (IGIHM)}

Building on these international discussions and global Indigenous community discussions on Indigenous data, the IGIHM was founded in 2005 [6]. The purpose of the group is to facilitate multi-national partnerships as well as to improve methods in the collection, analysis, interpretation and dissemination of data and information specific to the health of Indigenous populations [6]. The group has evolved to further global discussions on Indigenous data and data rights as well as enhance health knowledge and data pertaining to Indigenous peoples to work towards the elimination of health disparities. Wellness and resiliency have also
Table 1

COVID-19 cases and deaths in four countries, early January 2021

\begin{tabular}{lllll}
\hline & \multicolumn{1}{c}{ Cases } & $\begin{array}{c}\text { Cases } \\
\text { per } \\
\text { million }\end{array}$ & Deaths & $\begin{array}{c}\text { Deaths } \\
\text { per } \\
\text { million }\end{array}$ \\
\hline Australia & 28,536 & 1,112 & 909 & 35 \\
Canada & 624,553 & 16,474 & 16,317 & 430 \\
New Zealand & 2,186 & 437 & 25 & 5 \\
United States & $21,680,270$ & 65,301 & 367,196 & 1,108 \\
\hline
\end{tabular}

Source: Worldometer. Accessed online on 1/6/2021 at https:// www.worldmeters.info/coronavirus/?utm_campaign=homeAdUOA? Si\#countries.

become a focus of IGIHM. It is important to note that epidemics and pandemics are not new to Indigenous peoples in the four countries and throughout the world. Nor is this the first pandemic studied by IGIHM. A session was held about the effects of the $2009 \mathrm{H} 1 \mathrm{~N} 1$ pandemic in the four countries, which adversely affected Indigenous people. For example, an analysis of deaths among American Indians and Alaska Natives in the US found that mortality rates were four times higher than other Americans for H1N1 [11].

\section{COVID-19 in the four IGIHM countries}

The impact of the COVID-19 pandemic has varied enormously across the four countries. This variation appears to be affected by the speed and national coordination capabilities of the initial pandemic policy response of the nations. The availability of preventative public health measures and accessibility to health care are key features in lessening the impact of incident cases and the number of deaths from COVID-19. It is worth noting that three of the four countries have universal health care available to its citizens, while the United States does not.

The size and populations of these countries vary, as does the number and proportion of Indigenous peoples. The prevalence of COVID-19 cases and deaths, as of early January 2021 is shown in Table 1 [12]. Although figures are not separately listed for Indigenous and nonIndigenous peoples, the differences in impact among the four countries can be seen. Cases per million population range from 437 in New Zealand to 65,301 in the US. Death rates per million also varied from a low of 5 in New Zealand to a high of 1,108 in the US. Actual numbers of cases and deaths may vary slightly due to variability in the accuracy and timeliness of disease reporting. Differences in variants of the viruses may have been present but differences in prevention efforts and geographical features (i.e., islands versus land masses) are evident [12]. 
Table 2

COVID-19 indigenous cases and deaths in four countries - all ages

\begin{tabular}{lll}
\hline & Cases & Deaths \\
\hline Australia & 147 & 0 \\
Canada & 11,502 & 107 \\
New Zealand & 194 & 25 \\
United States & 107,025 & 3,704 \\
\hline
\end{tabular}

Sources: Australia - Department of Health, as of December 6, 2020. Canada - Government of Canada, as of January 2021. New Zealand - Ministry of Health Manatu Haurora, as of January 13, 2021. United States, Centers for Disease Control and Prevention. Cases and deaths, as of January 2021. NOTE: US cases and deaths refer to American Indians and Alaska Natives, but exclude Native Hawaiians.

\section{Summary of experiences of indigenous peoples by country}

Most Indigenous peoples experience health inequities through reduced access to health care, health promotion and preventative services, as well as reduced access to basic sanitation and clean water. Additionally, Indigenous peoples may also experience a greater burden and impact of both communicable and non-communicable diseases and their social determinants. Based on these known inequities, the extent of the impact of COVID19 upon Indigenous peoples across the globe is anticipated to highlight these known inequities, but will not be known for some time. However, a summary of the experiences to date across four nations is described in Table 1. The number of Indigenous COVID-19 cases and deaths is provided in Table 2 [13-16]. As mentioned previously, experiences from Australia and the US are presented in separate papers in this issue.

\section{Canada}

First Nation, Métis and Inuit communities in Canada responded variably to COVID-19. For the first eight months into the pandemic, most communities continued to thrive, safe from the coronavirus. Yet some communities were hard hit. For example, in northern Saskatchewan, where approximately 80 percent of the 40,000 residents identify as First Nations or Métis, COVID-19 infection rates were significantly greater than in the rest of the province. However, in late 2020 when Canada experienced its second wave, serious outbreaks began to occur in a number of communities previously free of COVID-19. Two examples are the Inuit community of Arviat, Nunavut and the northern Manitoba community of Shamattawa First Nation. In both cases, and in most others, the spikes in transmission were associated with the underlying health determinants
- overcrowded housing, lack of human and material resources, poverty.

In Nunavut Territory, with its greater than 90 percent Inuit population, COVID-19 infections had remained at zero for eight months, but between November 4 and December 7, the number of infections exploded to 219 in a territorial population of $36,000[17,18]$. Alarmingly, as of December 6, the majority (46/51) of the active cases in Nunavut were in a single isolated community - Arviat, pop. 2,500 [18].

First Nations in Manitoba were successful in keeping COVID-19 out of their communities until late 2020. In Shamattawa, Manitoba, a single externally introduced infection quickly exploded to 144 in a population of about 1300 as of December 5, 2020; this included a test-positivity rate of 68 percent [19]. On December 12, military aid began arriving in the community, but not before a quarter of the community of 1300 had tested positive [20].

On a larger scale, some 86 percent of on-reserve COVID-19 infections have occurred in the provinces of Alberta, Saskatchewan and Manitoba [21], despite having less than 40 percent of the First Nation population in Canada [18]. This serves as an indication of the unevenness of the susceptibility of our Indigenous communities, and that vigorous, coordinated emergency response measures are vital to prevent more outbreaks and protect population health [22].

\section{New Zealand}

On February 28, 2020, the first case of Covid-19 was reported, and the first death was reported on March 29 in Aotearoa-New Zealand, population 5,109,280 (estimate from January 2021) [23]. To date there have been 25 deaths and 2186 cases diagnosed, of which 2100 have recovered. In March 2020, the Aotearoa-New Zealand Government instructed the Ministry of Health to inform [24] a rapid response to the WHO declaration of a pandemic, closing borders to all non-residents on March 19 and ordering all returning to Aotearoa-New Zealand to self-isolate for two weeks. Formal managed isolation and quarantine (MIQ) was instituted April 10 [25]. Aotearoa-New Zealand's government introduced a four level Covid-19 alert system [26] March 21, and a nation-wide lockdown begun March 25, ended and April 27 with restrictions on maintaining physical distancing and the size of group gathering ending June 8. At present border control restrictions remain in place.

Māori, the Indigenous people of Aotearoa New Zealand (16.7 percent of the total population), ex- 
pressed concern about the impact of a pandemic on Māori [27] that was consistent with historical data [28]. The response by Māori communities and public health champions was effective and a COVID-19 Māori Health Response Plan [29] was developed and implemented. Rates of infection in Māori were predominantly related to imported cases [30,31] suggesting fears of poorer outcomes for Māori were justified. The response of Māori communities has been positive and one where community-based organisations and Māori health leaders acted and led to support the vulnerable who would be otherwise isolated during the nation-wide lock down [32-40].

\section{Future concerns}

At this point in time of early January 2021, there is good news about vaccines. Vaccines, many of which require two doses, have been administered in many countries to front line medical workers, those residing in congregate settings such as nursing homes and some of the elderly. Two dose vaccines require extensive planning, logistics and educational campaigns to encourage participation. Vaccine type and availability vary by nation with different vaccines having variable efficacy in both prevention and transmission. It is therefore important that there is transparency within nations to ensure that timely, relevant information is available to people. Of particular interest are the decision-making processes regarding who receives which vaccine and when they receive it. Further, it is critical to ensure that nations use existing registry systems or develop systems to collect the data on the administration of the COVID-19 vaccines so further research and accurate national reporting can occur. On the other hand, more contagious variants of COVID-19 have begun to spread, such as the so-called UK and South Africa strains, the latter of which may not be prevented by current approved vaccines $[41,42]$. Although it is unclear at the moment, these variants may increase contagion as much 50 to 70 percent. This would nonetheless result in drastic changes to the number of cases.

The effects of COVID on Indigenous communities are not limited to the burden of disease and loss of life. Since COVID-19 adversely affects the elderly, the culture and traditions of Indigenous communities themselves may be in danger. Indigenous languages, a touchstone of culture, are of particular concern. Many Indigenous languages are endangered and when elders who are among the last fluent native speakers of their lan- guage die from COVID the loss of the elders and their language is irreplaceable [43]. One Tribe in the United States, the Standing Rock Sioux, are deeming native speakers to be those who receive the vaccine early [44]. Besides languages, culture is in peril when Indigenous elders die. As Jason Salsman (Creek Tribe US) stated “... It's like we're having a cultural bookburning" [43]. Traditional healing practices are also in peril due to COVID-19. Although exact figures for elders who died from COVID are not available, the Navajo Nation in the US estimated that 65 percent of the COVID deaths were for persons over 60 and that this included traditional healers [43]. The continuity and evolving nature of Indigenous cultures and languages, which are reliant upon elders, may be in peril. This has not only happened in the US, but worldwide [45,46].

We should not assume that COVID-19 is the last pandemic that the world and Indigenous people will face. What we learn from COVID-19 will, hopefully, help with this next pandemic. This will be easier if nations invest in systems and processes that will provide for complete and accurate policy and direct required resources. Additionally, international progress may occur if the UN's Sustainable Development goals (SDGs) include disaggregation for Indigenous people.

\section{Acknowledgments}

The authors wish to thank Dr. Pieter Everaers, the IAOS Editor-in-Chief for this opportunity, members of IGIHM who generously contributed their thoughts and expertise and the leadership of Indigenous communities who have kept communities alive. Of special note are the contributions of Dr Amohia Boulton and Dr Kahu McClintock for documenting the responses of Māori communities. In New Zealand.

\section{References}

[1] Griffiths, K., Coleman, C., Al-Yaman, F., Cunningham, J., Garvey, G., Whop, L., Jackson Pulver, L., Waldon, J., Madden, R. The identification of Aboriginal and Torres Strait Islander people in official statistics and other data: critical issue of international significance. Statistical Journal of the IAOS. 2019; 35: 91-106. doi: 10.3233/SJI-180491.

[2] The First Nations Indigenous Governance Centre. First Nations data sovereignty in Canada. Statistical Journal of the IAOS 2019; 35: 47-69. doi: 10.3233/SJI-180478.

[3] Waldon, J. Identification of Indigenous people in AotearoaNew Zealand-Ngā mata o taku whenua. Statistical Journal of the IAOS. 35: 107-118. doi: 10.3233/SJI-180490. 
[4] Connolly, M., Gallagher, M., Hodge, F., Cwik, M., O'Keefe, V., Jacobs, B., Adler, A. Identification in a time of invisibility for American Indians and Alaska Natives in the United States. Statistical Journal of the IAOS. 2019; 35: 71-89. doi: 10.3233/SJI-180495.

[5] Santos, R., Guimarăes, B., Simoni, A., da Silva, L., Antunes, M., Damasco, F., Colman, R., Azevedo, M. The identification of the Indigenous population in Brazil's official statistics, with an emphasis on demographic censuses. Statistical Journal of the IAOS. 2019; 35: 29-46. doi: 10.3233/SJI-180471.

[6] Chino, M., Ring, I., Jackson-Pulver, L., Waldon, J., King, M. Improving health data for indigenous populations: The international group for indigenous health measurement. Statistical Journal of the IAOS. 2019; 35: 15-21. doi: 10.3233/SJI180479.

[7] Madden, R., Coleman, C., Mashford-Pringle, A., Connolly, M. Indigenous identification: past, present and a possible future. Statistical Journal of the IAOS. 2019; 35: 23-27. doi: 10.3233/SJI-180467.

[8] United Nations Economic and Social Council. United Nations Permanent Forum on Indigenous Peoples. Report on the First Session of the Permanent Forum on Indigenous Peoples. UN Doc. E/CN.19/2002/3/Rev.1, 2002. Accessed December 10, 2020. https://undocs.org/E/CN.19/2002/3/Rev.1.

[9] United Nations Economic and Social Council. United Nations Permanent Forum on Indigenous Peoples. Report on the Second Session of the Permanent Forum on Indigenous Peoples. UN Doc. E/C.19/2003/22, 2003. Accessed December 10, 2020. https://undocs.org/E/C.19/2003/22.

[10] United Nations Economic and Social Council. United Nations Permanent Forum on Indigenous Peoples. Report of the Workshop on Data Collection and Disaggregation for Indigenous Peoples, UN Doc. E/C.19/2004/2, 2004. Accessed December 10, 2020. https://undocs.org/E/C.19/2004/2.

[11] CDC Morbidity and Mortality Weekly Report (MMWR). Deaths related to 2009 pandemic influenza A (H1N1) among American Indians - 12 states, 2009. Accessed online on 12/14/ 2020 at https://www.cdc.gov $/ \mathrm{mmwr} / \mathrm{preview} / \mathrm{mmwrhtml} / \mathrm{mm}$ 6848a1.htm.

[12] Worldometer. Accessed online on January 6, 2021 at https:// www.worldmeters.info/coronavirus/?utm_campaign=homeAd UOA?Si\#countries.

[13] Commonwealth of Australia, Department of Health, as of December 6, 2020. Accessed online January 14, 2021: doi: 10. 33321/cdi.2020.44.92.

[14] Government of Canada, as of January 2021. Accessed online January 13, 2021 at https://www.sac-isc.gc.ca/eng/159862510 5013/1598625167707.

[15] New Zealand Ministry of Health Manatu Haurora, as of January 13, 2021. Accessed online https://health.govt.nz/ourwork/diseases-and-conditions/covid-19-novel-coronavirus/ covid-19-data-and-statistics/covid-19-case-demographics.

[16] Centers for Disease Control and Prevention. Cases and deaths, as of January 2021. Accessed online on January 14 2021: https://covid.cdc.gov/covid-data-tracker/\#demographics https://data.cdc.gov/NCHS/Deaths-involving-coronavirusdisease-2019-COVID-19/ks3g-spdg/data.

[17] CBC News. (2020 Oct 23) Confirmed COVID-19 Cases in Canada by Region. https://newsinteractives.cbc.ca/coronaviru stracker/.

[18] Statistics Canada. (2020 Dec 07) Census Profile, 2016 Census. https://www12.statcan.gc.ca/census-recensement/2016/dp$\mathrm{pd} / \mathrm{prof} /$ index.cfm?Lang=E.

[19] CBC News. (December 5, 2020) Rangers to help in Shamat- tawa, as COVID-19 cases in northern Manitoba First Nation climb. https://www.cbc.ca/news/canada/manitoba/military-ma rc-miller-shamattawa-first-nation-manitoba-covid-19-1.5830 118.

[20] CBC News. (December 12, 2020) Shamattawa First Nation in Manitoba receives more military support for COVID-19 battle. https://www.cbc.ca/news/canada/manitoba/shamattawacovid-19-military-1.5839206.

[21] Government of Canada, Indigenous Services Canada. (December 10, 2020) Confirmed cases of COVID-19. https://www.sacisc.gc.ca/eng/1598625105013/1598625167707.

[22] CBC News. (December 6, 2020) 'United team effort' key to success in overcoming Opaskwayak Cree Nation COVID-19 outbreak: chief. https://www.cbc.ca/news/canada/manitoba/ opaskwayak-cree-nation-covid-19-outbreak-1.58297741/15/ 2021.

[23] New Zealand statistics. Estimated Population of New Zealand Accessed online at https://www.stats.govt.nz/indicators/popu lation-of-nz.

[24] Ministry of Health. COVID-19 Health and Disability System Response Plan. 2020. https://health.govt.nz/publication/covid19-health-and-disability-system-response-plan.

[25] Ministry of Business, Innovation \& Employment (MBIE) Managed Isolation and Quarantine. https://www.miq.govt.nz/.

[26] New Zealand Government, New Zealand COVID-19 Alert Levels Summary. https://covid19.govt.nz/assets/resources/ tables/COVID-19-alert-levels-summary.pdf.

[27] McLeod, M., et al. COVID-19: we must not forget about Indigenous health and equity. Australian and New Zealand Journal of Public Health. 2020; 44(4): 253-256.

[28] Wilson, N., et al. Differential mortality rates by ethnicity in 3 influenza pandemics over a century, New Zealand. Emerging Infectious Diseases. 2012; 18(1): 71-77.

[29] Ministry of Health. COVID-19 Māori Response Action Plan 2020.

[30] Baker, M.G., Wilson, N., Blakely, T. Elimination could be the optimal response strategy for covid-19 and other emerging pandemic diseases. BMJ. 2020; 371: $\mathrm{m} 4907$.

[31] Jefferies, S., et al. COVID-19 in New Zealand and the impact of the national response: a descriptive epidemiological study. The Lancet Public Health. 2020; 5(11): e612-e623.

[32] McClintock, K., Boulton, A.F. Introduction, in Ko Tōku ara Rā Aotearoa-Our Journey, New Zealand Covid19 2020, McClintock, K., Boulton, A.F., Eds. Te K${ }^{-}$wai Rangahau, Te Rau Ora \& Whakauae Research Centre, Aotearoa, New Zealand. 2020. pp. 6-14.

[33] Butler, K. I pēhea tātou i whakaurungitia ai te rāhui - Navigating the lockdown, in Ko Tōku ara Rā Aotearoa-Our Journey, New Zealand Covid19 2020, McClintock, K., Boulton, A.F., Eds. Te K-1wai Rangahau, Te Rau Ora \& Whakauae Research Centre, Aotearoa, New Zealand. 2020. pp. 15-22.

[34] Baker, M. Māori Self Governing Hauora Organisations: Key performers in COVID-19 Pandemic, in Ko Tōku ara Rā Aotearoa-Our Journey, New Zealand Covid19 2020, McClintock, K., Boulton, A.F., Eds. Te K-1wai Rangahau, Te Rau Ora \& Whakauae Research Centre, Aotearoa, New Zealand. 2020. pp. 23-36.

[35] Moke, T. Raukura Hauora O Tainui, in Ko Tōku ara Rā Aotearoa-Our Journey, New Zealand Covid19 2020, McClintock, K., Boulton, A.F., Eds. Te K'-1wai Rangahau, Te Rau Ora \& Whakauae Research Centre, Aotearoa, New Zealand. 2020. pp. 37-40.

[36] King, F. COVID-19 Reflections on initial response Ngāti Porou Hauora, in Ko Tōku ara Rā Aotearoa-Our Journey, New 
Zealand Covid19 2020, McClintock, K., Boulton, A.F., Eds. Te $\mathrm{K}^{-}$iwai Rangahau, Te Rau Ora \& Whakauae Research Centre, Aotearoa, New Zealand. 2020. pp. 41-69.

[37] Boulton, A.F., Gifford, H. E tū ana tātou i roto i te waonui-o-tane, in Ko Tōku ara Rā Aotearoa-Our Journey, New Zealand Covid19 2020, McClintock, K., Boulton, A.F., Eds. Te $\mathrm{K}^{-}$1wai Rangahau, Te Rau Ora \& Whakauae Research Centre, Aotearoa, New Zealand. 2020. pp. 70-86.

[38] Eade, L., Luke, A. Te Tauihu o Te Waka a Māui COVID-19 Response He Waka Eke Noa, in Ko Tōku ara Rā Aotearoa-Our Journey, New Zealand Covid19 2020, McClintock, K., Boulton, A.F., Eds. Te $\mathrm{K}^{-}$iwai Rangahau, Te Rau Ora \& Whakauae Research Centre, Aotearoa, New Zealand. 2020. pp. 87-107.

[39] Leahy, H. \#Manaaki!20: A Te Waipounamu response to COVID-19, in Ko Tōku ara Rā Aotearoa-Our Journey, New Zealand Covid19 2020, McClintock, K., Boulton, A.F., Eds. Te $\mathrm{K}^{-}$1wai Rangahau, Te Rau Ora \& Whakauae Research Centre, Aotearoa, New Zealand. 2020. pp. 108-132.

[40] Camp, J., et al. He mahi kai takata, he mahi kai hoaka, in Ko Tōku ara Rā Aotearoa-Our Journey, New Zealand Covid19 2020, McClintock, K., Boulton, A.F., Eds. Te K' ${ }^{-}$wai Rangahau, Te Rau Ora \& Whakauae Research Centre, Aotearoa, New Zealand. 2020. pp. 133-141.
[41] CDC Science Briefs. Emerging SARS-COV-2 variants. Accessed online January 15, 2021 at https://www.cdc.gov/corona virus/2019-ncov/more/science-and-research/scientific-briefemerging-variants.html.

[42] Weisblum, T., Schmidt, F., Zhang, F., et al. Escape from neutralizing antibodies by SARS-CoV-2 spike protein variants. Accessed online January 15, 2021: https://elifesciences.org/ articles/61312.

[43] Healy, J., Blue, V.J. Cultural Crisis for American Indians as elders die. New York Times. January 12, 2021.

[44] Time, Associated Press. Standing Rock Sioux Tribe is prioritizing COVID-19 vaccines for those who speak native languages. January 1, 2021. Accessed online January 13, 2021 at https://time.com/5925745/standing-rock-tribe-vaccines-nati ve-languages/.

[45] McCoy, T., Traiano, H. 'There are no words': As coronavirus kills Indigenous elders, endangered languages face extinction. The Washington Post. Washington, DC. October 6, 2020.

[46] United Nations Department of Economic and Social affairs. The impact of COVID-19 on Indigenous peoples. Policy Brief No. 70. United Nations. May 2020. 